\title{
Formulation Of Low-Cost Poultry Feed Using Local Paddy Wastes
}

\author{
Tuan Badlishah Tuan Jusoh ${ }^{2,}$ *, Harizal Hamid ${ }^{3}$ Muhidin Arifin ${ }^{4}$, M. Hakimi ${ }^{1}$, Zuraida.K ${ }^{5}$ \\ 1 Department of Science and Biotechnology, Universiti Selangor, 45600 Selangor, Malaysia \\ 2 Department of Engineering, Universiti Selangor, 45600 Selangor, Malaysia \\ ${ }^{3}$ Statistical and Decision Science Studies, UiTM Shah Alam,40450 Selangor,Malaysia.
}

*Correspondence: mhakimi@ unisel.edu.my

DOI: DOI: 10.29322/IJSRP.11.6.2021.p11381

http://dx.doi.org/10.29322/IJSRP.11.6.2021.p11381

\begin{abstract}
Feed is the most expensive input for poultry production, and the availability of low-cost, high-quality feeds is critical for the poultry industry's expansion. Energy sources, supplemented by plant protein sources and animal protein sources, make up the majority of poultry diets. Maize is the most widely used energy source around the world, and soybean meal is a popular plant protein source. In certain countries, however, other grains like wheat and sorghum, as well as plant protein meals like canola meal, peas, and sunflower meal, are still commonly used. The most important aspect of the poultry industry is feed composition and formulation, as different feed compositions contribute to differences in overall poultry quality, taking into account broiler health, growth enhancement, poultry farm hygiene, and meat quality. Bird management and experimental design: Five-hundred-day old strain of chicks was randomly divided into ten groups of fifty birds each. Each group was randomly assigned to one of the four diets in a Completely Randomized Design (CRD) with factorial arrangement of treatment. Each treatment was replicated five times. Birds were housed in deep litter pen of $5 \times 5 \mathrm{~m}$ with wood haven as bedding material. Feed and water were served ad libitum while medication and vaccination were carried out according to the standard practice in modern poultry management. Birds were fed starter diet for the first four weeks and finisher diet for the remaining four weeks of eight-week duration of the study. The quality of broiler's meat can be defined as the microstructure of the muscle post mortem affect both aspects of color and also water holding capacity (WHC). Color is a major determinant of appearance and water holding capacity of technological value. Meat color will be evaluated immediately after deboning using a colorimeter. The CIE system color profile of lightness $\left(\mathrm{L}^{*}\right)$, redness $\left(\mathrm{a}^{*}\right)$ and yellowness $\left(\mathrm{b}^{*}\right)$ will be measured by reflectance colorimeter using illuminant source $\mathrm{D}$, while $\mathrm{pH}$ value is measured 24 hours postmortem, by inserting a portable $\mathrm{pH}$ meter. Cooking loss will be determined as percentage of weight lost during roasting $\left(220^{\circ} \mathrm{C}\right.$ for $\left.30 \mathrm{~min}\right)$. Total lipid will be determined in raw and roasted breast and thigh meat with skin. Water holding capacity of muscle samples will be measured using the methodology of Wierbicki and Deatherage. From the quality test of livestock meat products formulating livestock fed from shows the following characteristics where the meat is firmer with less fat. The meat content of livestock contains less water making the meat more durable.
\end{abstract}

Index Terms- feed, poultry, diets, meat quality

\section{INTRODUCTION}

$\mathrm{F}$

or thousands of years, poultry production has been a part of human society. It is critical that manufacturing and marketing are adapted to local environments and related value chains, that nutrient cycling and efficient utilization of all goods are maximized, and that genetic diversity is preserved to ensure that it continues to make successful and sustainable contributions to healthy human society. [1] The increasing worldwide demand for stable protein sources has triggered a new discussion about food security such as the use of local resources. [2] Feed is the most expensive input for poultry production, and the availability of 
low-cost, high-quality feeds is critical for the poultry industry's expansion. Poultry require a consistent supply of energy, protein, essential amino acids, minerals, vitamins, and, most importantly, water for optimal performance and health.[3]

Energy sources, supplemented by plant protein sources and animal protein sources, make up the majority of poultry diets. Maize (corn) is the most widely used energy source around the world, and soybean meal is a popular plant protein source. In certain countries, however, other grains like wheat and sorghum, as well as plant protein meals like canola meal, peas, and sunflower meal, are still commonly used. Fishmeal and meat meal are the primary sources of animal protein. Almost all developing countries are net importers of these ingredients; Africa and Asia's poultry feed industries depend on imports, which deplete their foreign exchange reserves. In these countries, the semi-commercial and commercial industries are often forced to curtail their compounded feed production.[4]

Recent advancements in poultry nutrition have mainly focused on three main areas: developing a better understanding of nutrient metabolism and requirements, determining the availability of nutrients in feed ingredients, and formulating low-cost diets that meet nutrient requirements and supply. Depending on how many hulls are cut and how the oil is extracted, soybean meal contains 40 to 48 percent crude protein. Soybean protein provides a strong balance of essential amino acids as compared to other oilseed meals, and it can be used to supplement most cereal-based diets. Soybean meal has a higher level of amino acid abundance than other oilseed meals. Soybean meal has a higher level of amino acid abundance than other oilseed meals. The amount of metabolizable energy is also significantly higher than in other oilseed meals.[5]

A lack of corn and soybeans in the Asia-Pacific region would limit the poultry industry's growth in the coming decade. In this regard, the use of locally available energy feedstocks should be emphasized. This study looks at the potential feeding gain and nutritional limitations of certain carbohydrate and protein sources using local rice bran, with a particular emphasis in Malaysia.[6] The most important aspect of the poultry industry is feed composition and formulation, as different feed compositions contribute to differences in overall poultry quality, taking into account broiler health, growth enhancement, poultry farm hygiene, and meat quality. Modern poultry diets are now formulated based on the amount of Metabolizable Energy (ME) in the diet.[7]

\section{Literature Review}

Rice (Oryza sativa) is the world's most common staple food, particularly in East and South Asia, the Middle East, Latin America, and the West Indies. It produces more than a quarter of all calories consumed by humans worldwide. It is the world's second most important cereal crop and the primary source of nutrition for half of the world's population. It is grown in at least 114 countries, with a global output of 645 million tons; Asian farmers produce roughly $90 \%$ of the total. Rice bran is made up of pericarp, aleurone, sub aleurone plate, which germ, and is the brown outer layer of the rice kernel. It contains appreciable quantities of nutrients like protein, fat, and dietary fiber. It also contains significant amounts of minerals such as $\mathrm{K}, \mathrm{Ca}, \mathrm{Mg}$, and $\mathrm{Fe}$. The presence of antioxidants such as tocopherols, tocotrienols, and -oryzanol increases the likelihood of rice bran being used as a functional component in humans to treat life-threatening disorders.[8] 
Rice (fiber) bran has 12-15 percent protein and is one of the most attractive and plentiful milling by-products. The reduction in quality \&quantity of protein will increase as well as the availability of numerous nutrients, taking into account the prohibition of rice. During fermentation, a quantity of enzymes such as alpha-amylase, $\alpha$-Acetolactate, decarboxylase, $\beta$-Endoglukanase, HemicellulasE, PhytasE, Maltogenic amylase, \&xylanase produce inoculum microbial fermentations, which have capability to damage fiber.[9]

Feed formulations play a big role in determining the quality of broiler's meat. The type of wheat used when feeding whole wheat as a part of the diet can influence the incidence of quality of broiler's outcome in term of healthy and meat quality [10]. It is also generally accepted that excess crude protein levels in the feed will increase the production of uric acid in the kidneys, leading to wet droppings that are rich in nitrogen, which will result in a high prevalence of contact dermatitis [11]. Feed composition based on the soy bean formulation at higher rate as their main sources of protein have been reported to contribute to an irritant litter in broiler's resulting in sticky droppings and sticky litter and leading to an increase in the incidence of footpad dermatitis. There is an effect of dietary fat quality on litter surface friability [12], and over-drinking caused by too high salt content in the feed can also result in wet litter, which in turn may increase the prevalence of contact dermatitis. Furthermore, the type of wheat used when feeding whole wheat as a part of the diet can influence the incidence of footpad dermatitis [13]. It is also generally accepted that excess crude protein levels in the feed will increase the production of uric acid in the kidneys, leading to wet droppings that are rich in nitrogen, which will result in a high prevalence of contact dermatitis [14]. Therefore, they conclude that the quality of poultry meat is a complex and multivariate properties. The meat output per breeder is composed of at least three parameters growth, feed conversion; and breeder effectiveness.

In formulating broiler diets, the main criteria to on the formulation is the usage of the crude protein (CP), because protein is the critical constituent of poultry diets, and together with the other main nutrients such as carbohydrates, fat, water, vitamins, and minerals, is essential for life [15]. Proteins are polymers that are composed of amino acids, which are linked together by peptide bonds. Proteins are broken down and hydrolyzed in the digestive system into amino acids. Then, after absorption, the amino acids will be assembled and metabolized to form proteins that are used in the building of different body tissues [16]. However, protein is also one of the most expensive ingredients in poultry diets. Therefore, nutritionally and economically, proper protein usage is essential in all feeding systems, and wasteful usage increases the cost of production. In general, vegetable (plant) protein sources are nutritionally unbalanced and poor in certain essential amino acids and this decreases their biological value as they may not furnish the required limiting amino acids needed by birds for egg and meat production. Poultry nutritionists have paid more attention to the use of animal protein sources to create a balanced diet [17].

Animal proteins are well balanced in terms of essential amino acids that are necessary for body growth and development, but they are expensive for commercial broiler production. Therefore, they are usually used to complement the amino acid balance in the diets rather than as the main protein source. Also, the concern associated with disease transmission from products of animal origin is also taken into consideration. In general, the quality of animal protein sources is dependent on the composition of the raw material used. Animal protein supplements are derived from poultry and poultry processing; meat packing and rendering operations; fish and fish processing, and milk and dairy process [18]. Bone meal, meat meal, poultry meal, hydrolyzed feather meal and to a lesser extent blood meal have all been used as important feedstuffs for poultry feeding [19]. Animal proteins are a beneficial component of poultry diets because they offer a high level of protein/amino acids, a high level 
of available phosphorus, reasonable amounts of other minerals, and moderate levels of energy. Thus, it is necessary to include one or more of these animal proteins sources in chicken diets. Hatchery by-products, feather and blood meals, and spent hens, have also been used for feeding no ruminant animals [20].

\section{Experimental Method}

Feed preparation: The rice bran that was used for the study was obtained from a local rice miller within the study area and then oven-dried to about $13 \%$ moisture content to avoid mold. Seven diets were formulated. Diets 1 was the control where no rice bran were and into formulation and diets 2 were add 5 percent of rice bran and reduce 5 percent of ground corn until 30 percent of rice bran and reduce of 30 percent of corn in diet 7, they contained xylanase enzyme at the rate of $150 \mathrm{~g} /$ tone of diet. All diets were iso-nitrogenous and iso-energetic and meet the minimum nutrient requirement of broiler birds (NRC 1994). The gross compositions of the diets are presented in Table 1.

TABLE 1; Diets for chicks used in Experiment 1 of rice bran study

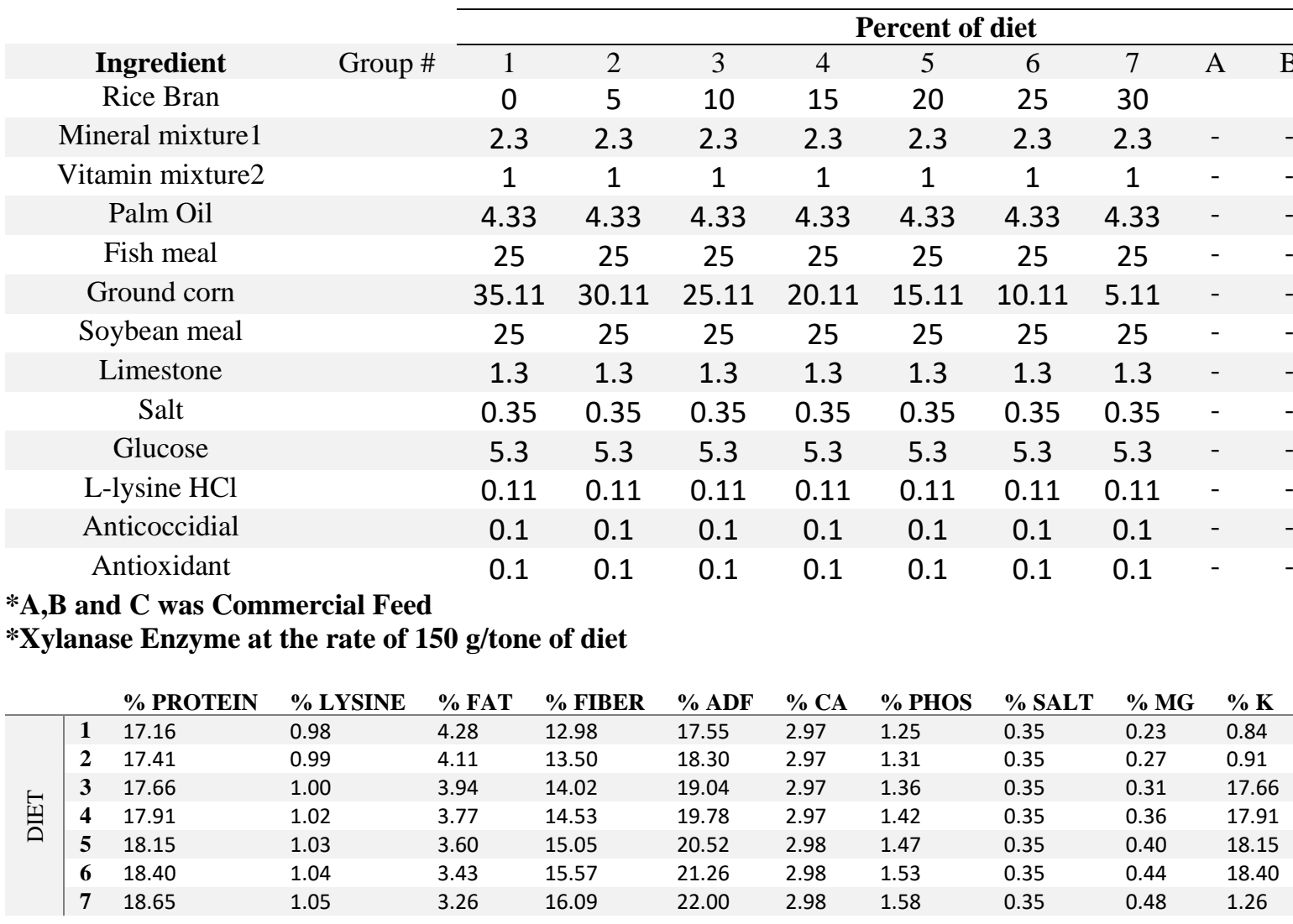

Bird management and experimental design: Five-hundred-day old strain of chicks was randomly divided into ten groups of fifty birds each. Each group was randomly assigned to one of the four diets in a Completely Randomized Design (CRD) with factorial arrangement of treatment. Each treatment was replicated five times. Birds were housed in deep litter pen of 1x2 m with wood haven as bedding material. Feed and water were served ad libitum while medication and vaccination were carried out according to the standard practice in modern poultry management. Birds were fed starter diet for the first four weeks and finisher diet for the remaining four weeks of eight-week duration of the study. 
Data collection: Data were collected daily on feed intake and weekly on weight gain. Feed intake was calculated as difference in the weight of feed given and left over after $24 \mathrm{~h}$. Weight gain was determined as the difference in the weight of the birds after 7 days period. Feed: grain ratio was calculated from feed intake and weight gain. Mortality was recorded and expressed as the percentage of the number of birds at the commencement of the experiment. Cost of feed was calculated from the cost of ingredients used in feed preparation. Feed cost per kilogram live weight gain was calculated from feed cost and feed: gain ratio.

Carcass analysis: Carcass analysis was carried out using ten birds per treatment. Live weight and dressed weight were taken using electronic weighing balance and expressed as percentage of live weight of the birds. Weights of abdominal fat and gizzard were also taken and expressed as percentage of the live weight. Length of the different parts of the gastro intestinal tract was taken using measuring tapes and the lengths expressed in $\mathrm{cm} / 100 \mathrm{~g}$ body weight of the birds.

\section{Result and Discussion}

\subsection{Meat Quality}

The quality of broiler's meat can be defined as the microstructure of the muscle post mortem affect both aspects of color and also water holding capacity (WHC). Color is a major determinant of appearance and water holding capacity of technological value. Meat color will be evaluated immediately after deboning using a colorimeter. The CIE system color profile of lightness $\left(\mathrm{L}^{*}\right)$, redness $\left(\mathrm{a}^{*}\right)$ and yellowness $\left(\mathrm{b}^{*}\right)$ will be measured by reflectance colorimeter using illuminant source $\mathrm{D}$, while $\mathrm{pH}$ value is measured 24 hours postmortem, by inserting a portable $\mathrm{pH}$ meter. Cooking loss will be determined as percentage of weight lost during roasting $\left(220^{\circ} \mathrm{C}\right.$ for $\left.30 \mathrm{~min}\right)$. Total lipid will be determined in raw and roasted breast and thigh meat with skin. Water holding capacity of muscle samples will be measured using the methodology of Wierbicki and Deatherage.

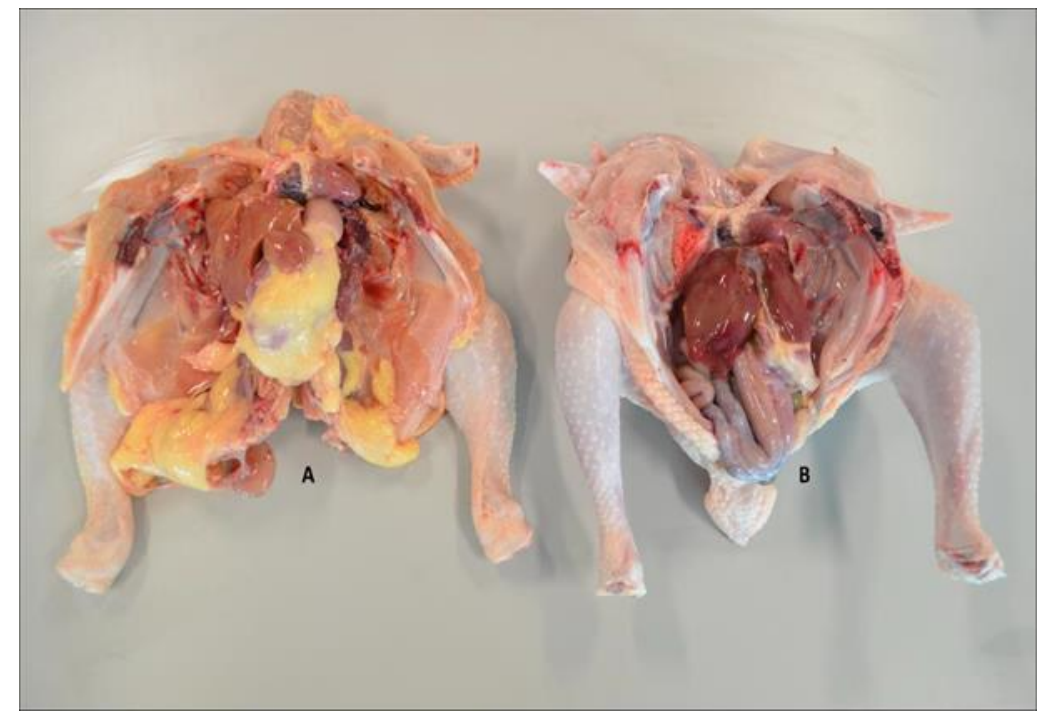

Figure 1: Overall comparison of meat appearance between two feed formulations: (A) Meat from conventional feed formulation. (B) Meat from experiment feed formulation. 


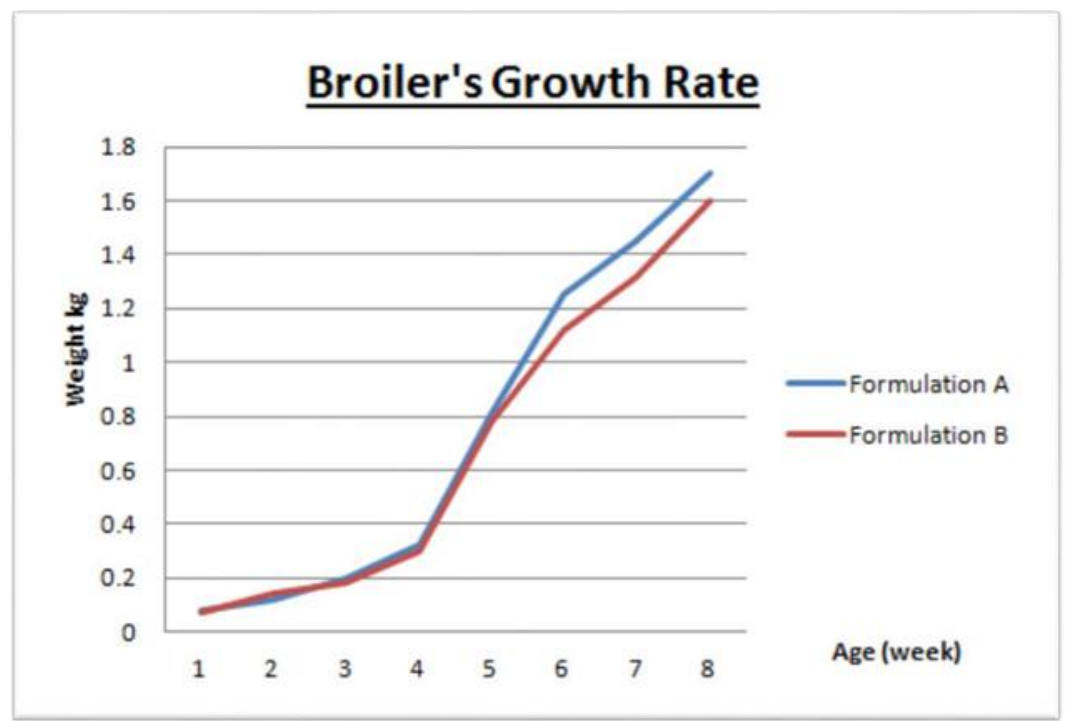

Figure 2: Comparison of Broilers Growth Rate (weight / age: g / week) between two feed formulations (A and B)

\subsection{Statistical analysis}

Data was analyzed by descriptive statistics (mean, standard deviation, and range). ANOVA with Tukey's test was performed, in order to determine statistical differences among examined parameters between farms $(\mathrm{p}<0.05)$. Pearson's correlation coefficient (r) was generated using the correlation procedures.

\begin{tabular}{|c|c|c|}
\hline Week & Mean Weight A & Mean Weight B \\
\hline 1 & 0.08 & 0.07 \\
\hline 2 & 0.12 & 0.14 \\
\hline 3 & 0.201 & 0.185 \\
\hline 4 & 0.325 & 0.302 \\
\hline 5 & 0.812 & 0.782 \\
\hline 6 & 1.25 & 1.12 \\
\hline 7 & 1.45 & 1.32 \\
\hline 8 & 1.7 & 1.6 \\
\hline
\end{tabular}

\subsection{Meat Color Analysis}

From both samples A and B, we can conclude that for breast meat (pectoralis major) at 24 hours after slaughtering group A shows that the meat score rate for brightness already at early phase of PSE reading whereas broiler from group B score only 50.62 within the allowable range for normal meat. After preservation of 10 days, the score rate for group A already entered in PSE range as the reading increased to 59.25 whereas for group B, broiler's meat shows consistency of brightness score rate with increasing of value at only $4 \%$ from 50.62 to 52.83 yet still at normal score rate for broiler's meat brightness. One major problem in poultry industry recently is the increasing of PSE (pale, soft and exudative) meat in broiler's production (PSE)-like $\left(\mathrm{L}^{*}>53, \mathrm{pH} 24 \mathrm{~h}<5.7\right)$ and 60 normal $\left(46<\mathrm{L}^{*}<53,5.7<\mathrm{pH} 24 \mathrm{~h}<6.1\right) \mathrm{K}$. Li, Y. Y. Zhao 2015. 
Table 2a: Meat color analysis result for 24 hours

\begin{tabular}{|l|r|r|l|}
\hline Sample Mean & $\mathbf{L}^{*}$ & \multicolumn{1}{|c|}{$\mathbf{a}^{*}$} & \multicolumn{1}{c|}{$\mathbf{b}^{*}$} \\
\hline Pectoralis major A & 50.6230 & 3.7995 & 1.0055 \\
\hline Pectoralis major B & 55.2120 & 4.6060 & 1.3170 \\
\hline Regio tibio-femoralis A & 51.8190 & 4.9445 & 1.4345 \\
\hline Regio tibio-femoralis B & 46.1820 & 4.1930 & 1.1605 \\
\hline
\end{tabular}

Table 2b: Meat color analysis result after preserving for ten (10) days in chiller at -4 degree $\left(\mathrm{C}^{0}\right)$

\begin{tabular}{|l|r|r|l|}
\hline Sample Mean & $\mathbf{L}^{*}$ & \multicolumn{1}{l|}{$\mathbf{a}^{*}$} & \multicolumn{1}{c|}{$\mathbf{b}^{*}$} \\
\hline Pectoralis major A & 52.8535 & 3.8045 & 1.0590 \\
\hline Pectoralis major B & 59.2590 & 3.9452 & 2.3135 \\
\hline Regio tibio-femoralis A & 51.1980 & 4.9990 & 1.3390 \\
\hline Regio tibio-femoralis B & 44.1830 & 3.7995 & 1.0055 \\
\hline
\end{tabular}

\section{4 pH Result Analysis}

From the graph a slightly significant of quality level for group B can be seen with more constant Ph drop within time period comparing to group A. Broiler's meat from group A having a rapid Ph drop at 4 hours to 24 hours leading to Ph score at 3.95 at the end of analysis. For group B the last recorded value at 24 hours was 4.96.

Table 3a: Ph result analysis for Pactoralic Major A

\begin{tabular}{|c|c|c|c|}
\hline Ph analysis result & $\begin{array}{c}\text { Pectoralis } \\
\text { major A } \\
(\mathbf{0 . 2 5 h})\end{array}$ & $\begin{array}{c}\text { Pectoralis } \\
\text { major A (4h) }\end{array}$ & $\begin{array}{c}\text { Pectoralis } \\
\text { major A (24h) }\end{array}$ \\
\hline $\mathrm{N}$ & 20 & 20 & 20 \\
Mean & 6.0675 & 4.8655 & 3.95 \\
Std. Error of Mean & 0.11677 & 0.1079 & 0.13791 \\
Minimum & 5.21 & 4.11 & 3.12 \\
Maximum & 7 & 6 & 5.52 \\
Std. Deviation & 0.52223 & 0.48254 & 0.61675 \\
& & & \\
\hline
\end{tabular}




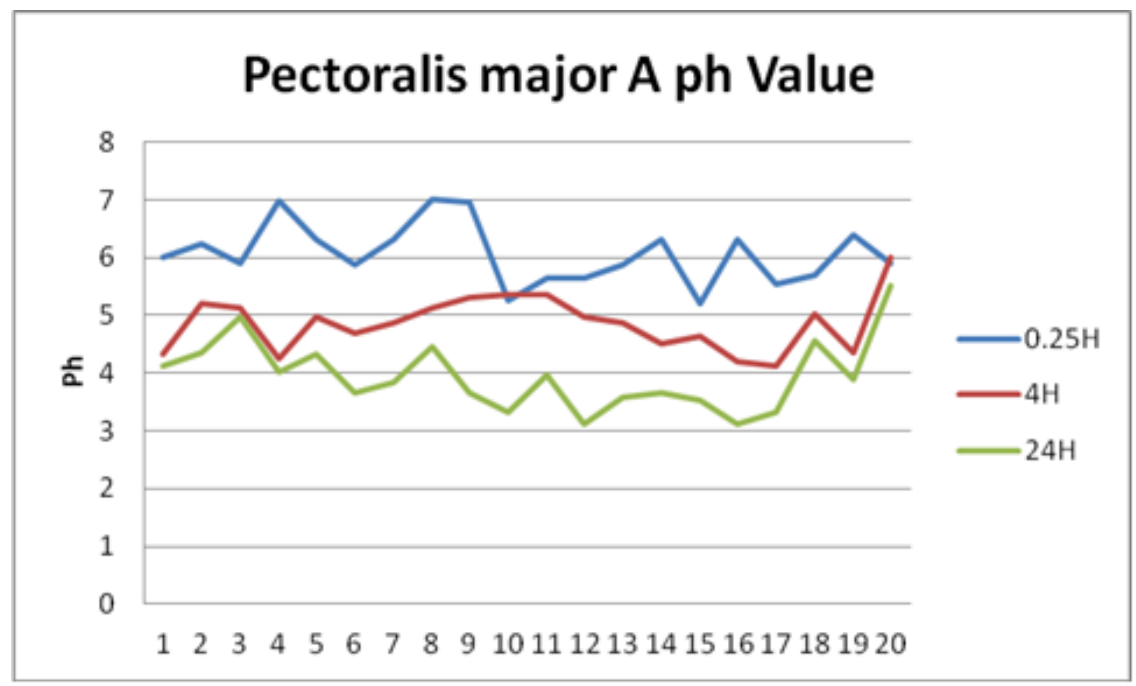

Figure 3 : Pectoralis Major A ph vs Time

Table 3b: Ph result analysis for Pactoralic Major B

\begin{tabular}{|c|r|r|r|}
\hline Ph analysis result & $\begin{array}{c}\text { Pectoralis } \\
\text { major B } \\
(\mathbf{0 . 2 5})\end{array}$ & $\begin{array}{c}\text { Pectoralis } \\
\text { major B (4h) }\end{array}$ & $\begin{array}{c}\text { Pectoralis } \\
\text { major B (24h) }\end{array}$ \\
\hline N & 20 & 20 & 20 \\
Mean & 6.2915 & 6.0745 & 4.9645 \\
Std. Error of Mean & 0.11536 & 0.11215 & 0.0972 \\
Minimum & 5.23 & 5 & 4.32 \\
Maximum & 7.12 & 7.05 & 5.66 \\
Std. Deviation & 0.5159 & 0.50155 & 0.4347 \\
\hline
\end{tabular}

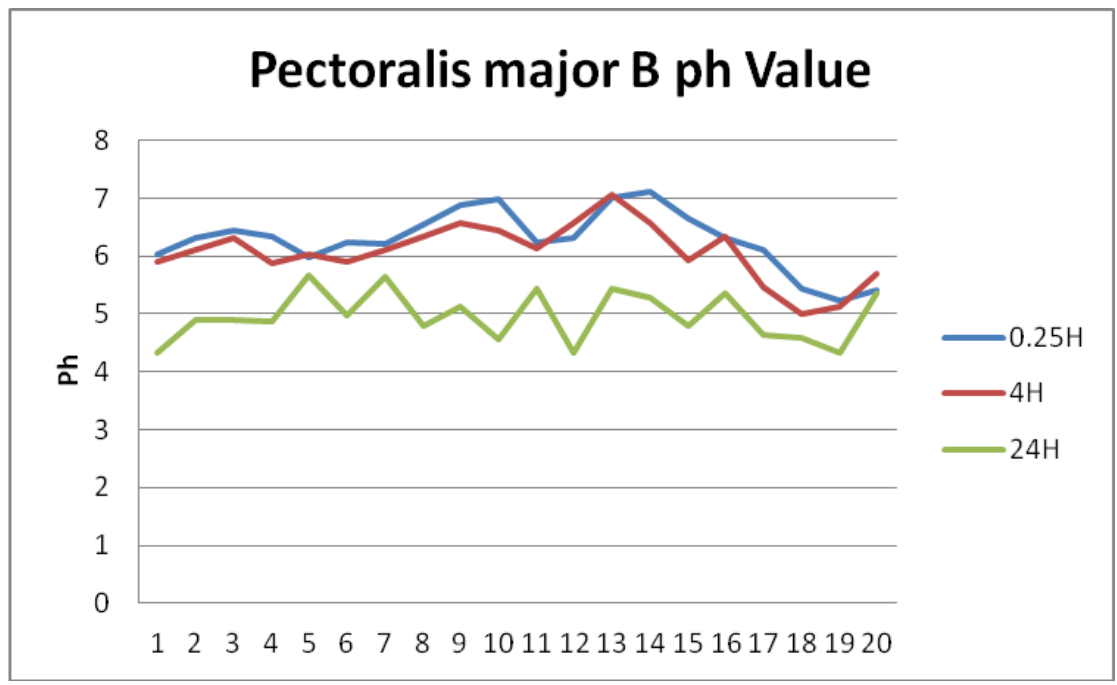

Figure 4 : Pectoralis Major B ph vs Time 


\subsection{Water Holding Capacity}

Water-holding capacity of meat is defined as the ability of the postmortem muscle (meat) to retain water even though external pressures (e.g., gravity, heating) are applied to it. The characteristic of water-holding capacity is not trivial. One of the most prevalent broiler meat quality issues is unacceptably high moisture loss (often described as purge or drip loss) in fresh and minimally processed products. Unacceptably high moisture loss from fresh product as purge or drip.

The mean for Pectoralis major's group A moisture lost in gram are recorded at 30.96 higher than mean for Pectoralis major's group B moisture lost in gram which at 24.9150. Rapid losses in broiler's meat contribute to the increasing of Ph value of the meat.

\subsection{Cooking Loss}

The mean for Pectoralis major's group A moisture lost in gram are recorded at 30.9650 higher than mean for Pectoralis major's group B moisture lost in gram which at 24.9150. Rapid losses in broiler's meat contribute to the increasing of $\mathrm{Ph}$ value of the meat. Potential to use rice bran in order to replace corn and soybean meal as main ingredient for poultry feed. Oil palm fiber not to suitable to be used as poultry feed because of high concentration of silica damage digestion system of the chicken.

\section{Conclusion}

From the quality test of livestock meat products formulating livestock fed from shows the following characteristics where the meat is firmer with less fat. The meat content of livestock contains less water making the meat more durable.

\section{Acknowledgments}

This research is supported by State Government of Selangor for the financial support through Geran Penyelidikan Kerajaan Negeri Selangor 2018 (GPNS18) vote number GPNS-01/UNISEL/18-055. The authors also acknowledge members of the for their effort and contribution to the research. 


\section{REFERENCES}

[1] Alders, R.; Costa, R.; Gallardo, R.A.; Sparks, N.; Zhou, H. Smallholder poultry: Leveraging for sustainable food and nutrition security. In Encyclopedia of Food Security and Sustainability; Elsevier: Amsterdam, The Netherlands, 2018; pp. 340-346.

[2] Bay-Larsen, I.; Risvoll, C.; Vestrum, I.; Bjorkhaug, H. Local protein sources in animal feed—Perceptions among arctic sheep farmers. J. Rural Stud. 2018, 59, 98-110.

[3] Thirumalaisamy, G. \& Muralidharan, J \& Senthilkumar, s \& Sayee R, Hema \& Priyadharsini, M. (2019). Cost-Effective Feeding Of Poultry. International journal of Environmental Science and Technology. 5. 3997-4005.

[4] Ravindran, Velmurugu. (2013). Poultry feed availability and nutrition in developing countries. Poultry Development Review. 60-63.

[5] F. Arrutia, E. Binner, P. Williams, K.W. Waldron Oilseeds beyond oil: press cakes and meals supplying global protein requirementsTrends Food Sci Technol, 100 (2020), pp. 88-102

[6] V. Ravindran \& R. Blair (1991) Feed resources for poultry production in Asia and the Pacific region. I. Energy sources, World's Poultry Science Journal, 47:3, 213-231, DOI: 10.1079/WPS19910018

[7] R.R. Alvarenga, M.G. Zangeronimo, P.B. Rodrigues, L.J. Pereira, R.C. Wolp, E.C. Almeida Formulation of diets for poultry; The importance of prediction equations to estimate the energy values Arch. Zootec., 62 (R) (2013), pp. 1-11

[8] Mian Kamran Sharif, Masood Sadiq Butt, Faqir Muhammad Anjum \& Saima Hafiz Khan (2014) Rice Bran: A Novel Functional Ingredient, Critical Reviews in Food Science and Nutrition, 54:6, 807-816, DOI: 10.1080/10408398.2011.608586

[9] Prof. J. M. L. Gulati, Prof. S. S. Nanda. (2020). Rice Bran: A Review. International Journal of Modern Agriculture, 9(3), 456 461.

[10] Dirk Hoehler, A. Lemme V. RavindranW. L. Bryden and H. S. Rostagno Feed Formulation in Broiler Chickens Based on Standardized Ileal Amino Acid Digestibility 2005.

[11] Kellems and Church (1998), Waldroup, P. W. [2001. Dietary nutrient allowances for chickens and turkeys.

[12] Olivo R, Soares AL, Ida EI, Shimokomaki M. Dietary vitamin E inhibits poultry PSE and improves meat function proprieties. J Food Biochem. 2001; 25(4): 271-283.

[13] K. Li, Y. Y. Zhao, Z. L. Kang Reduced functionality of PSE-like chicken breast meat batter resulting from alterations in protein conformation 2015

[14] Ravindran V. Poultry feed availability and nutrition in de veloping countries: main ingredients used in poultry feed formulations. Poultry development review 2007.

[15] Rome, Italy: F. A. O.; 2013. p. 67e9.Aviagen. Ross 308 broiler management guide. 2009.

[16] Cheeke PR. Livestock feeds and feeding. 3rd ed. Upper Saddle River, New Jersey: Pearson Prentice Hall; 2005.

[17] Barbut S, et al. (2008). "Progress in reducing the pale, soft and exudative (PSE) problem in pork and poultry meat". Meat Science. 79: 46-63.

[18] Pesti, G. M., Bakalli, R. I., Qiao, M., \& Sterling, K. G. (2002). A comparison of eight grades of fat as broiler feed ingredients. Poultry science, 81(3), 382-390.

[19] Beski, S. S., Swick, R. A., \& Iji, P. A. (2015). Specialized protein products in broiler chicken nutrition: A review. Animal Nutrition, 1(2), 47-53

[20] Moritz, J. S., \& Latshaw, J. D. (2001). Indicators of nutritional value of hydrolyzed feather meal. Poultry Science, 80(1), 7986. 


\section{AUTHORS}

First Author - Tuan Badlishah bin Tuan Jusoh, Degree in Biomedical Science, Univerisiti Selangor, badlishah@unisel.edu.my . Second Author - Harizal Hamid, MSC in Physic, Universiti Malaya, harizalhamid@ unisel.edu.my

Third Author - Accosiate Professor Ir Muhidin Bin Ariffin, Phd in Mech, Univerisiti Selangor, irmuhidin@unisel.edu.my Fourth Third Author - Zuraida Binti Khairudin zuraida k@tmsk.uitm.edu.my.

Correspondence Author - M Hakimi Abdullah, Degree in Biotechnology, Univerisiti Selangor, mhakimibio@unisel.edu.my, mhakimibio@gmail.com, phone number+-0192097763 